\title{
The Influence of Immersion in Certain Electrolytic Solutions upon Permeability of Plant Cells.
}

\author{
BI
}

\section{MAUD WILLIAMS, B.SC. \\ With two Figures in the Text.}

$\mathrm{M}$ $\mathrm{UCH}$ recent work upon the cells of plants shows the permeability of the cell protoplasmic membrane to undergo modification during immersion in certain solutions. Such immersion may cause the exit of constituents of the sap which are normally unable to penetrate the membrane, or it may render possible the entrance of materials from outside the cell, which are unable to pass into the cell in the ordinary course.

Czapek, as a result of his study of the influence of ethers, alcohols, \&c. (1), comes to the conclusion that surface tension of the liquid surrounding the material is the chief factor in producing these abnormal permeabilities. According to this writer 'all substances of the most different chemical character began to injure the cell just when the surface tension had reached the critical value' (2). This critical surface tension is stated to be 'about two-thirds relatively to that of water'. On the other hand, there are numerous experiments which show that the cell-membrane may be rendered permeable to the electrolytes contained in the vacuole by immersion in electrolytic solutions of which the surface tensions are far removed from Czapek's critical value. Thus Miss Hind records abnormal permeability produced by immersion in very dilute acids (3), while Stiles and Jørgensen obtain similar results for many solutions, including magnesium and sodium chlorides (4).

Since surface tension considerations alone cannot explain the alterations of permeability other possibilities must be considered, and it is of interest to find how far the time of immersion in a particular solution affects the question.

An endeavour has here been made to deal throughout with one type of plant cell and

(a) to find what solutions are capable of rendering the protoplasm permeable to one particular material to which it is normally impermeable ;

[Annals of Botany, Vol. XXXII. No. CXXVIII. October, 1918.] 
(b) to find if there be any connexion between the concentration of the solution in which the cells are soaked and the time of immersion necessary to affect the protoplasm.

\section{METHODS AND MATERIAL.}

It was decided to deal with cells containing tannin, and to use ferric chloride as the material to which the membrane was to be rendered permeable.

In many plants cells occur which are rich in tannin. This substance occurs, in such cases, in solution in the cell sap, and in the particular plant used is usually insufficient by itself to produce coloration of the cell. The protoplasm of the healthy cell is impermeable to the tannin and, for very long periods at least, it is impermeable to ferric chloride solution in the strength used ( 0.2 gramme per 100 c.c.).

As a consequence, sections of the plant can be soaked for a matter of two hours in the ferric chloride without a blue coloration appearing in the cell, because the tannin and iron solution cannot come in contact. When the membrane has been altered, however, soaking for three minutes in the ferric chloride will produce a clear, easily recognizable blue colour in the cell.

In order, as far as possible, to equalize diffusion effects, sections must be examined after a fixed time in the iron solution. The short interval above mentioned was chosen in order that the influence of the ferric chloride itself upon permeability, if any, should be negligible.

The cells chosen were situated in surface strips taken from the leafstalks of London Pride (Saxifraga umbrosa). Under the upper epidermis the tannin-containing cells occur in chains, separated by tracts of cells without tannin. The cells are large, rectangular ones, which are easy to study, and the tissue is in good condition for the greater part of the year. The particular plants used were all grown upon the same kind of soil, and all strips used, except in preliminary experiments, were washed in a large quantity of distilled water for twenty-four hours to remove tannin from the torn cells, before immersion in the electrolyte chosen.

Before one could judge whether the abnormal permeability was general in any test, it was necessary to know approximately what proportion of the cells probably contained tannin in any section. To ascertain this point preliminary experiments were made with strips treated with I per cent. caffeine solution. This liquid readily penetrates the cell membrane and unites with the tannin to give a heavy precipitate, which causes the cell to darken.

A number of these experiments were made on various dates, and the cells with, and without, the precipitate were counted. No sections showed fewer than 45 per cent. of the cells to contain tannin; the usual result was 
about 50 per cent., while in a few cases as high as 64 per cent. was reached.

In the experiments with the electrolytic solutions, bottles holding 30 c.c. of the liquid chosen were used for the immersion of each five or six sections. Sections were removed after known times, soaked in the ferric chloride, transferred to a slide and mounted in more of the ferric chloride under a large cover-slip, and examined after three minutes altogether in contact with the iron salt. The change of permeability was considered complete if traces of blue could be seen appearing in about half the cells of the section excluding marginal cells. These latter were excluded because it was possible they might have been injured in the preparation of the material. The colour observed rapidly deepened during the next few minutes. The low power had therefore to be used to consider a section as a whole; the high power was afterwards used on individual cells to study the appearance of the protoplasm.

Since such methods are open to many sources of error no great degree of accuracy was aimed at in preparing the electrolytic solutions. The ordinary 'pure' chemicals of a laboratory were used, and a solution of each made up. Small quantities were withdrawn and diluted as required for the separate tests. The ferric chloride was made up freshly every few days.

To accompany the experiments upon each concentration sections from the same part of the plant as those being immersed in the salt solution were left in distilled water, and examined from time to time.

These 'control' experiments showed that the cells became injured, in some cases, after soaking for three days in water alone, so it was thought unwise to experiment over periods much above those quoted later. In consequence of this the influence of very dilute solutions of the salts could not be studied.

Rough experiments were first made for each concentration of electrolytic solution used. If, after a certain time of immersion no blue appeared upon the application of the ferric chloride, either the change in the protoplasm had not taken place, or the tannin had had time to diffuse out of the cell. To find which of these possibilities was correct one could either pour a little alcohol over the solution, or heat the slide to kill the cells, to allow the iron compound to pass in, if it had not already been able to do so.

These rough tests served to give the time needed for the change in permeability between limits of half to two hours, according to the nature of the experiment.

The sections in the bottles already mentioned were accordingly left undisturbed for the shorter time limits, and specimens were then removed at intervals of five minutes to twenty minutes according to circumstances, 
and tested. Care was taken that all these sections were from leaves of as nearly as possible the same size and condition, in the same rosette of the plant.

All experiments were carried on at the ordinary room temperature, and no corrections were possible for the effect this somewhat fluctuating temperature might have upon the permeability.

\section{OBSERVATIONS.}

If the rectangular cells were examined from time to time certain changes could be seen. The first thing to be noticed was the fact that the protoplasm, after short immersion in the electrolytic solution, shrunk away from the cell wall and formed threads and spherical masses. Treatment with pure water at these early stages was sufficient to restore the protoplasm to its normal form, so that these changes were connected with osmotic changes.

After a certain period of immersion in each case, when the sections were removed and treated with the ferric chloride, distinct blue coloration was seen in the plasmolysed masses of the protoplasm. Cells examined at this stage of immersion without ferric chloride showed a very granular appearance in the protoplasm, this effect being especially marked in the experiments with barium chloride and nitrate.

It was found that periods of immersion which allowed of blue tinting being obtained in the masses of protoplasm also served approximately to render the cell membrane permeable to the tannin within it, because a blue liquid was often seen also in the space between the shrunken protoplasm and the cell wall.

Although permeability to both tannin and ferric chloride seemed to be produced by approximately the same periods of immersion, the membrane did not become permeable, at this stage, to the red material so frequently found in cells of tannin-bearing plants. In this particular plant the red pigment occurs in cells which do not actually contain the tannin, and is particularly abundant in early spring. This colouring matter is soluble in water, and passes out of the cell after longer periods in the electrolytes.

It was frequent to obtain sections showing tracts of cells stained deep blue by the tannin reaction, side by side with tracts showing a clear rose colour. A stronger iron solution than that used for the tests was able to combine with the rose pigment and produce a greenish-brown precipitate within the special cells.

Results given below show details for five electrolytic solutions which were found capable of rendering the protoplasm permeable to the 0.2 per cent. iron chloride. It is intended to carry out tests on a series of salts to find whether there is any general connexion between concentration and time of immersion necessary to produce the given change. 
Electrolytic Solutions upon Permeability of Plant Cells. 595

\section{RESULTS.}

No. I. $\quad \mathrm{Al}_{2} \mathrm{Cl}_{6} \mathrm{I}_{2} \mathrm{H}_{2} \mathrm{O}$.

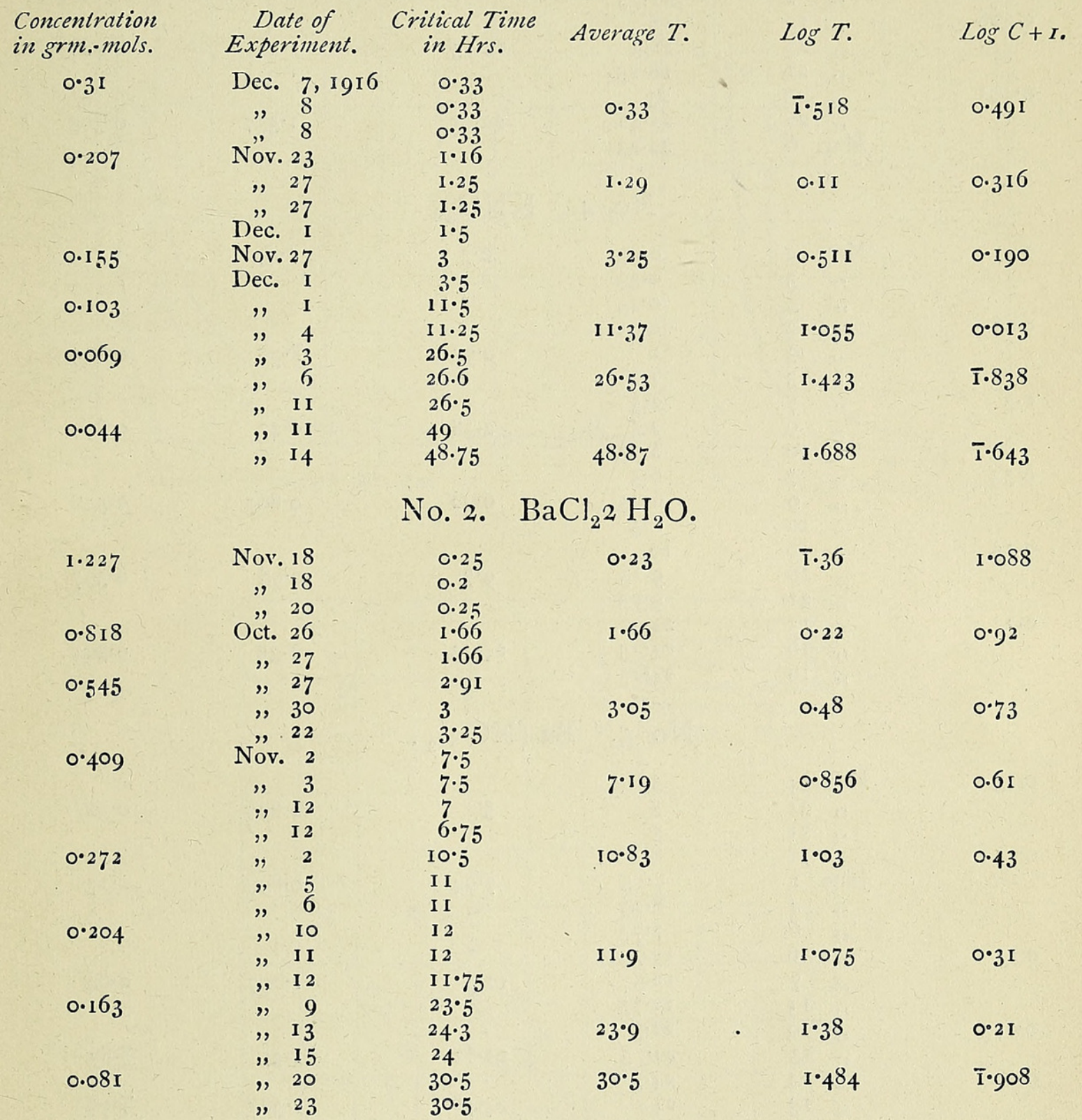

No. 3. $\mathrm{KCl}$.

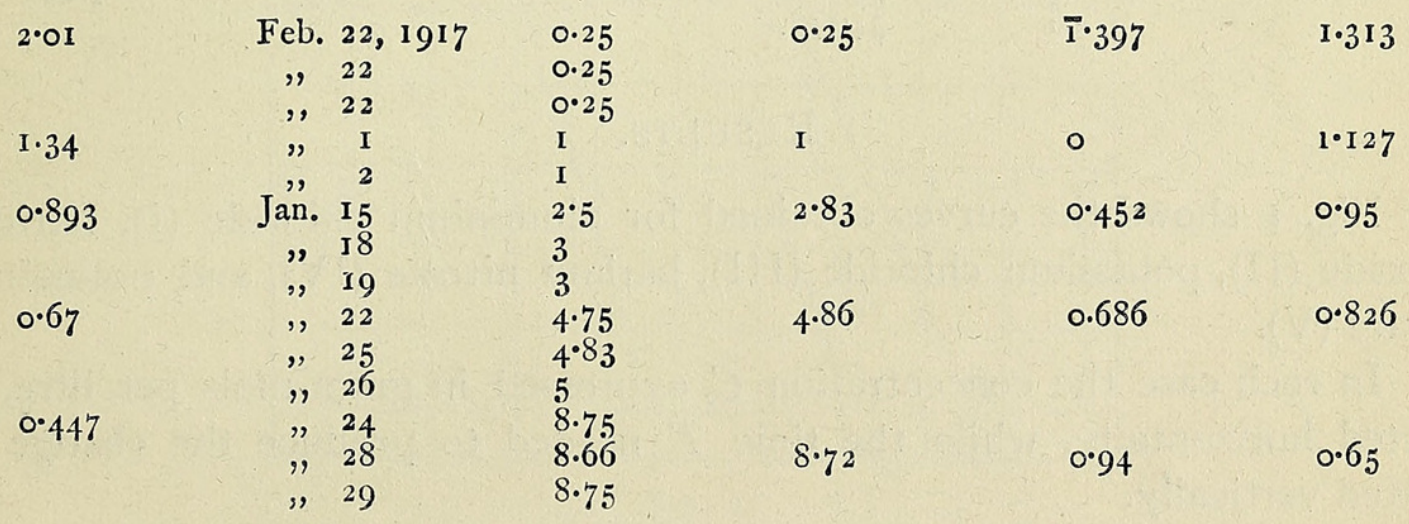


596 Williams. - The Influence of Immersion in Certain

\begin{tabular}{|c|c|c|c|c|c|c|c|}
\hline $\begin{array}{l}\text { Concentration } \\
\text { in grm.-mols. }\end{array}$ & $\begin{array}{r}D c \\
\text { Expe }\end{array}$ & $\begin{array}{l}\text { ate of } \\
\text { erimen }\end{array}$ & & $\begin{array}{l}\text { Critical Time } \\
\text { in Hrs. }\end{array}$ & Average $T$. & $\log T$. & $\log C+I$ \\
\hline 0.337 & Jan. & & 917 & II $\cdot 75$ & & & \\
\hline & Feb. & - I & & 12 & II $1 \cdot 83$ & $1 \cdot 07$ & 0.527 \\
\hline 0.268 & ", & $\begin{array}{r}2 \\
19\end{array}$ & & $\begin{array}{l}11 \cdot 75 \\
18\end{array}$ & & & \\
\hline & $"$ & 20 & & 18.5 & 18.25 & $I \cdot 26 \mathrm{t}$ & 0.428 \\
\hline & $"$ & $2 \mathrm{I}$ & & $18 \cdot 25$ & & & \\
\hline 0.201 & ", & 22 & & 23 & & & \\
\hline & Mä. & $\begin{array}{r}26 \\
.6\end{array}$ & & $\begin{array}{l}22 \cdot 42 \\
22.83\end{array}$ & $22 \cdot 75$ & $1 \cdot 357$ & $0.3 \circ 3$ \\
\hline & & & & No. 4 . & $\mathrm{KNO}_{3}$ & & \\
\hline I & May & 2 & & 0.33 & 0.3 & $\bar{I} \cdot 47$ & I \\
\hline & ", & 3 & & 0.33 & & & \\
\hline & $"$ & 3 & & 0.25 & & & \\
\hline 0.66 & $"$ & 2 & & $0.9 \mathrm{I}$ & & & \\
\hline & $"$ & 3 & & I & 0.97 & $T \cdot 98$ & 0.819 \\
\hline & ", & 3 & , & I & & & \\
\hline 0.5 & ", & 7 & & $2 \cdot 5$ & & & \\
\hline & ", & 9 & & $2 \cdot 5$ & $2 \cdot 5^{8}$ & $0.4^{I}$ & 0.699 \\
\hline & ," & 10 & & $2 \cdot 75$ & & & \\
\hline 0.33 & $"$ & $\begin{array}{l}7 \\
9\end{array}$ & & $\begin{array}{l}6 \cdot 5 \\
6 \cdot 25\end{array}$ & $6 \cdot 42$ & 0.807 & 0.518 \\
\hline & ", & 10 & & $6 \cdot 5$ & & & \\
\hline 0.25 & ", & Io & & 10 & & & \\
\hline & $"$ & 18 & & $9 \cdot 25$ & $9 \cdot 7$ & 0.98 & 0.397 \\
\hline & ", & $2 \mathrm{I}$ & & 9.75 & & & \\
\hline 0.2 & ", & I3 & & 24.5 & & & \\
\hline & ", & 16 & & $24^{\circ} 25$ & 24.33 & I. 39 & 0.301 \\
\hline & $"$ & 16 & & $24 \cdot 25$ & & & \\
\hline & & & & No. $5 \cdot \quad B$ & $\left(\mathrm{NO}_{3}\right)_{2}$. & & \\
\hline 0.23 & May & 24 & & 5 & & & \\
\hline & $"$ & $3 I$ & & 5 & 5 & 0.699 & 0.36 \\
\hline & " & $3 \mathrm{I}$ & & 5 & & & \\
\hline 0.15 & " & $3^{I}$ & & 8 & & & \\
\hline & June & I & & $7 \div 75$ & $7 \cdot 94$ & 0.899 & 0.17 \\
\hline & $"$ & 4 & & $8 \cdot 25$ & & & \\
\hline & $"$ & 6 & & $7 \cdot 75$ & & & \\
\hline O.I I & $"$ & 6 & & $\begin{array}{l}12.25 \\
12.5\end{array}$ & & r. & 0.04 \\
\hline & $"$ & $\begin{array}{c}7 \\
11\end{array}$ & & $12 \cdot 75$ & $12 \cdot 5$ & 1.097 & 0.04 \\
\hline 0.075 & ", & IO & & 22.5 & & & \\
\hline & $"$ & I3 & & $22 \cdot 75$ & $22 \cdot 62$ & $I \cdot 35$ & $\overline{\mathrm{I}} \cdot 87$ \\
\hline $0.05^{8}$ & $"$ & 12 & & $24 \cdot 5$ & & & \\
\hline & ", & I3 & & 24 & $24 \cdot 4$ & $1 \cdot 387$ & $\overline{1} \cdot 56$ \\
\hline & $"$ & I3 & & $24 \cdot 75$ & & & \\
\hline 0.046 & ", & I9 & & 33 & & & \\
\hline & $"$ & 24 & & $34^{\circ} 5$ & $33^{\circ} 9$ & $1 \cdot 53$ & $\overline{\mathbf{I}} \cdot 66$ \\
\hline & ", & 26 & & $34^{2} \cdot 5$ & & & \\
\hline
\end{tabular}

\section{RESULTS.}

Fig. I shows the curves obtained for aluminium chloride (I), barium chloride (II), potassium chloride (III), barium nitrate (IV), and potassium nitrate $(\mathrm{V})$.

In each case the concentration $C$, expressed in gram-mols per litre, is plotted horizontally, while the time $T$ needed to produce the change is plotted vertically. 
Electrolytic Solutions upon Permeability of Plant Cells. 597
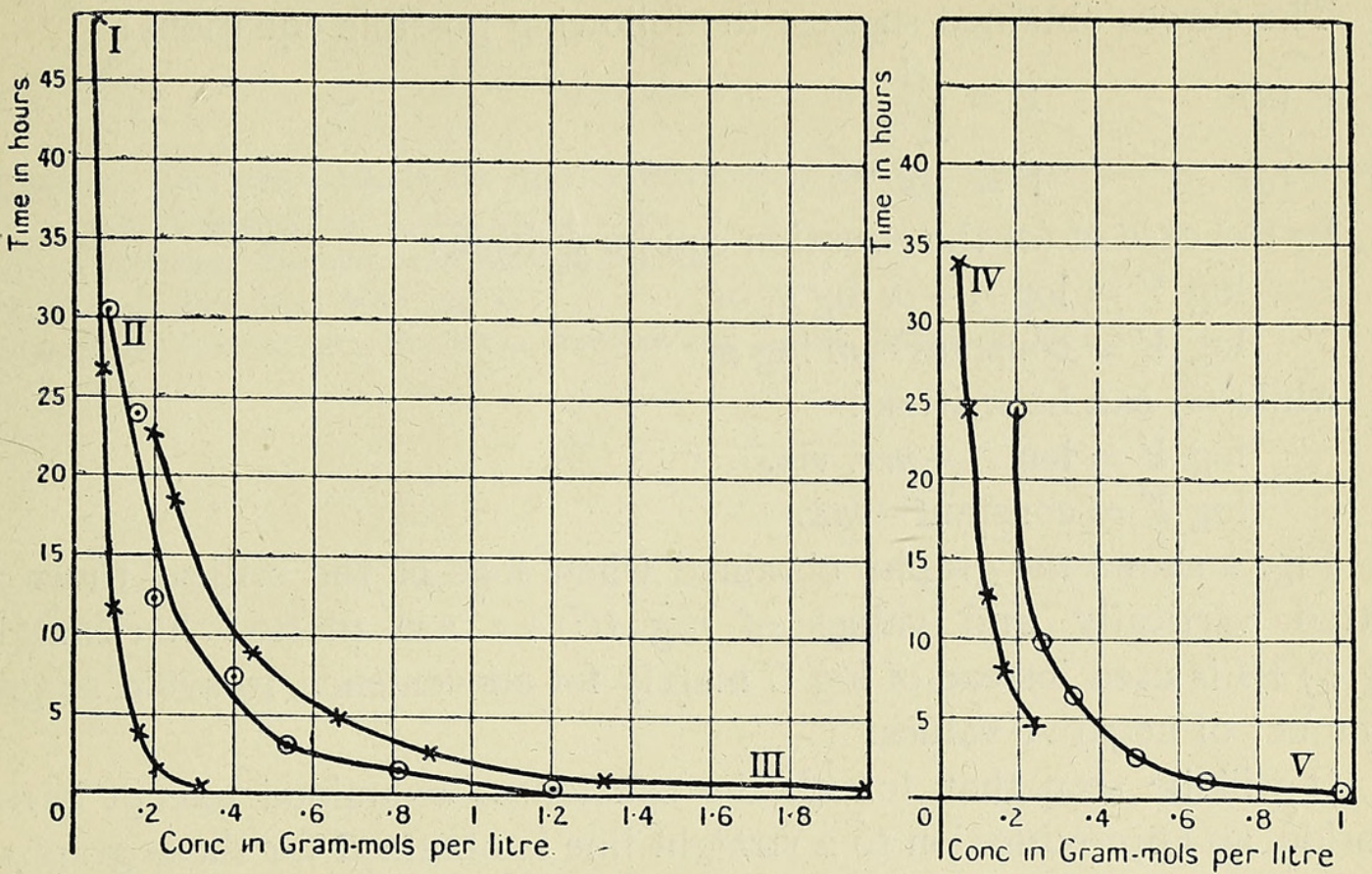

Fig. I.

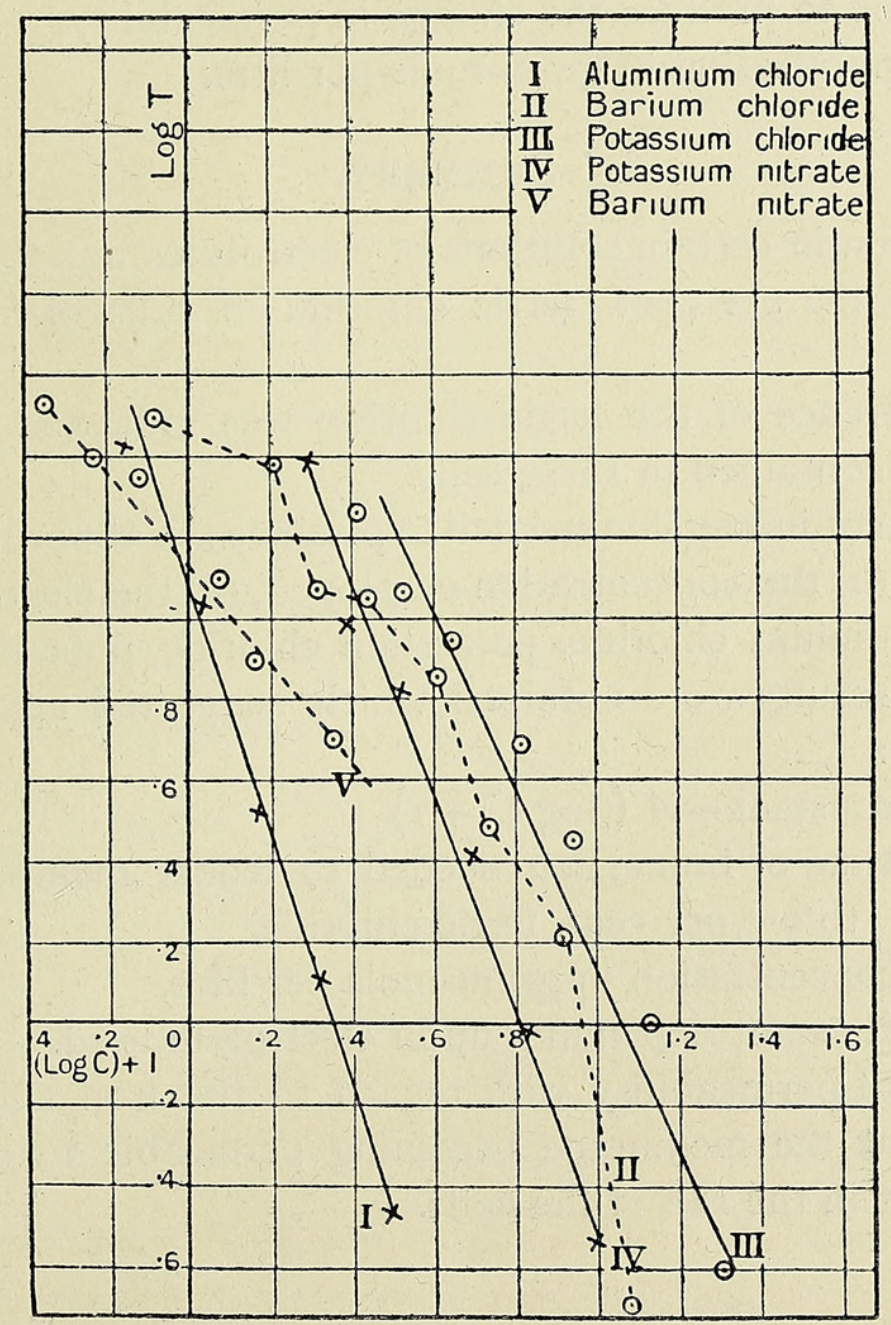

FIG. 2. 
The curves obtained suggest the following possible equations:

$$
\begin{aligned}
& Y=\frac{A}{X^{m}} \\
& Y=A e^{-m x}
\end{aligned}
$$

In the case of $(a)$ the equation can be written:

$\log Y=\log A-m \log x$, or

$\log Y=$ constant $-m \log x$.

while $(b)$ can be written :

$\log Y=\log A-m x$, viz.

$\log Y=$ constant $-m x$.

Fig. 2 shows the graphs obtained when logs of the critical times are plotted vertically and values of $\log (C)+\mathrm{I}$ are plotted horizontally. $(\log C)+\mathrm{I}$ is used instead of $\log C$ merely for convenience, to avoid so great a number of negative values.

It will be seen that for all the substances examined, except barium chloride, an approximation to a straight line is obtained for these graphs in Fig. 2, suggesting that over the limited periods studied

$\log T=$ constant $-A((\log C)+\mathrm{I})$, where

$T=$ time to produce the change in permeability,

$C=$ concentration in gram-mols per litre.

\section{SUMMARY.}

I. Immersion in certain solutions of electrolytes was found to produce permeability to 0.2 per cent. ferric chloride in cells of 'London Pride' petioles.

2. The entrance of the ferric chloride was indicated by its reaction with the tannin contained in these cells.

3. The time of immersion needed to produce the abnormal permeability depended upon $(a)$ the concentration employed, $(b)$ the electrolyte chosen.

4. For aluminium chloride, potassium chloride, potassium nitrate, and barium nitrate, results were obtained which suggested approximations to the relationship :

$$
\log T=\text { constant }-A((\log C)+\mathrm{I})
$$

where $T=$ time of immersion needed to render membrane permeable to 0.2 per cent. ferric chloride, $C=$ concentration in gram-mols per litre, $A=$ constant depending upon electrolyte used.

5. Abnormal permeability with regard to the iron chloride could be produced without the membrane becoming permeable to a rose-coloured material frequent in the sap of the cells. 
Electrolytic Solutions upon Permeability of Plant Cells. 599

\section{BIBLIOGRAPHY.}

1. CzAPEK : Über eine Methode zur direkten Bestimmung der Oberflächenspannung der Plasmahaut von Pflanzenzellen. Jena, I9II.

2. : Chem. Phenomena in Life, pp. $42,43$.

3. M. Hind : Ann. Bot., April, 1916.

4. Stiles and Jørgensen: Studies in Permeability. Ann. Bot., July, 19r5 


\section{$2 \mathrm{BHL}$ Biodiversity Heritage Library}

Williams, Maud. 1918. "The influence of immersion in certain electrolytic solutions upon permeability of plant cells." Annals of botany 32, 591-599. https://doi.org/10.1093/oxfordjournals.aob.a089694.

View This Item Online: https://www.biodiversitylibrary.org/item/238284

DOI: https://doi.org/10.1093/oxfordjournals.aob.a089694

Permalink: https://www.biodiversitylibrary.org/partpdf/320237

\section{Holding Institution}

Smithsonian Libraries

\section{Sponsored by}

Biodiversity Heritage Library

\section{Copyright \& Reuse}

Copyright Status: Not in copyright. The BHL knows of no copyright restrictions on this item.

This document was created from content at the Biodiversity Heritage Library, the world's largest open access digital library for biodiversity literature and archives. Visit BHL at https://www.biodiversitylibrary.org. 